\title{
APPLICATION OF QFD METHOD IN FITNESS FOOTWEAR PRODUCTION
}

\author{
Alina IOVAN-DRAGOMIR*, Alexandra LUCA \\ "Gheorghe Asachi" Technical University, Faculty of Textile - Leather and Industrial Management, 28 D. Mangeron, lasi, \\ Romania \\ Received: 12.02 .2018 \\ Accepted: 15.06 .2018 \\ https://doi.org/10.24264/lfj.18.2.11
}

APPLICATION OF QFD METHOD IN FITNESS FOOTWEAR PRODUCTION

ABSTRACT. In order to obtain a better product it is important to integrate the consumer requests in all production levels, starting with research, design and till the end of production process. One of the most popular methods used to increase the quality of a product is Quality Function Deployment. The result of application of QFD method in footwear is presented in this paper. The consumer requests are expressed by completing a questionnaire. The group of respondents consists of men and women, between 20 and 50 years old, who practice fitness more than twice a week. Their opinions are inventoried, analysed and in the end, the most important ones are the input information for the quality house. The result of the study is a better product and for the producers a guideline to obtain a product according to consumer expectations.

KEY WORDS: Quality Function Deployment, fitness footwear, quality house.

APLICATIII ALE METODEI QFD ÎN PRODUCȚIA ÎNCĂLȚĂMINTEI PENTRU FITNESS

REZUMAT. Pentru obținerea unui produs de încălțăminte superior este important să fie integrate cerințele consumatorilor în toate fazele de obținere, începând de la cercetare, proiectare și până la finalul procesului de producție. Una din cele mai populare metode de a crește calitatea unui produs este desfășurarea funcției calității (QFD). Această lucrare prezintă aplicarea metodei pentru un produs de încălțăminte. Opiniile consumatorilor au fost exprimate cu ajutorul unui chestionar. Grupul țintă este format din bărbați și femei, cu vârste cuprinse între 20 și 50 de ani, care practică fitness mai mult de două ori pe săptămână. Cerințele lor au fost analizate, iar cele mai importante au ajutat la construcția casei calității. Rezultatul studiului îi ajută pe producători să obțină produse conform așteptărilor consumatorilor. CUVINTE CHEIE: QFD, încălțăminte sport, casa calității

APPLICATIONS DE LA MÉTHODE QFD DANS LA PRODUCTION DES CHAUSSURES SPORT

RÉSUMÉ. Afin d'obtenir un produit de qualité supérieure, il est important d'intégrer les exigences du consommateur dans toutes les phases de la production, à partir de la recherche, de la conception et jusqu'à la fin du processus de production. L'une des méthodes les plus populaires pour augmenter la qualité d'un produit est le déploiement de la fonction qualité (QFD). Cet article présente l'application de cette méthode dans la production de chaussures. Les opinions des consommateurs ont été exprimées à l'aide d'un questionnaire. Le groupe cible comprend des hommes et des femmes de 20 à 50 ans qui pratiquent le fitness plus de deux fois par semaine. Leurs besoins ont été analysés, et les plus importants ont contribué à construire la maison de la qualité. Le résultat de l'étude aide les producteurs à obtenir les produits attendus par les consommateurs.

MOTS CLÉS : déploiement de la fonction qualité, chaussures sport, maison de la qualité

* Correspondence to Alina IOVAN-DRAGOMIR, "Gheorghe Asachi" Technical University, Faculty of Textile - Leather and Industrial Management, 28 D. Mangeron, lasi, Romania, adragomir@tex.tuiasi.ro 


\section{INTRODUCTION}

In last years, the footwear market has been under a strong and constantly increasing pressure. It is a pressure of overproduction produced by the big number of the actors involved, like companies, designers, sellers. The level of the competition is very high and, nowadays, to stay on the market means care about the customer and "to hear" the voice of the consumer.

According to Yoji Akao, the founder of QFD method, "Quality Function Deployment (QFD) is a method for satisfying customers by translating their demands into design targets and quality assurance points." This method can be used to design any product, process or activity. QFD method is applying a graphic model named Quality House.

In this paper, for a good and easy understanding of this method, is presented a case study for sports shoes used for fitness.

\section{MATERIALS AND METHODS}

The case study has two parts: the investigation of client's demands using a questionnaire, and building a Quality House.

The method used for the investigation of consumer's demands was a questionnaire. The quiz contained 10 items exploring the sports shoes, the raw materials they are made from, brand, price, followed by four questions regarding demographic aspects such as gender, age, education level and income level of the respondent.

The sample consists of consumers (male and female) who practice fitness at the gym. The clients were asked to be part of the study and complete the survey. The sample consists of 30 individuals, 21 men and 9 women, ages 18-40, who exercise more than two times per week.

In process of Quality House Development are five important steps:

Step 1: Establish requirements for the product design;

Step 2: Setting product functions;

Step 3: Establish the product concept taking in consideration the similar products of two competitors;
Step 4: Preliminary design of the product;

Step 5: Final constructive design of the product.

\section{EXPERIMENTAL}

\section{Consumer's Demands}

The first part of the survey investigates the type of shoes used during exercises, the materials they were made from, the brand and the price.

For more than half of respondents, $53.33 \%$, the brand is the key factor when they make a purchase, followed by materials and price, $23.33 \%$.

The second part of the survey is to find out the interest of the consumers regarding characteristics of the sport for fitness.

For fitness, $66.7 \%$ of the respondents prefer textile shoes because of their flexibility and comfort, $30 \%$ of interviewees are wearing shoes made from textiles and leather. They prefer textiles due to the comfort, dryness of the foot, the weight of the shoe and the style.

The features pursued by consumers are: $70 \%$ want comfort (dry feet, without cold/warm sensation), $53.3 \%$ look up for flexibility, $10 \%$ prefer light shoes and another characteristic is to wash easily (on washing machine).

When it comes to lock system, $53.3 \%$ of respondents prefer shoe lace, followed by elastic lace (30\%) and Velcro system (10\%).

\section{The Building of the Quality House}

The Quality House construction may be difficult at the first sight, but QFD is based on simple concepts rather than high technology. Developing process of Quality House must focus on consumers' needs, because they are the target group; the QFD team must identify these needs and using marketing skills, they have to find a way in order to satisfy the consumers.

\section{Establish Requirements for the Product Design}

Consumer needs are often unclear and vague technically speaking. Some of these needs are not realistic so the QFD team has to decide if they will be accepted or not. The 
needs were classified as primary and secondary requirements (table 1 ).

Table 1: Primary and secondary requirements

\begin{tabular}{ll}
\hline TO BE... & \\
\hline Made of textile & $\begin{array}{l}\text { Sole materials } \\
\text { Upper materials } \\
\text { Lining materials } \\
\text { Color }\end{array}$ \\
$\begin{array}{l}\text { Blue / black } \\
\text { Price: } 200-300 \text { lei }\end{array}$ & \\
Flexible 50 Euro) & Flexibility \\
Dry feeling & Sole hardness \\
& Air permeability \\
Lock system & Water permeability \\
\hline
\end{tabular}

\section{Setting Product Functions}

Consumers' needs should be expressed using technicalvocabulary to be easily understood by specialists in the design and production departments. Technical characteristics must be measureable because the results will be compared with the normal size and they will be part of the product starting from the design to the whole life cycle of the product.

The purpose of Quality House is to design a new product or to modify an existing one in order to satisfy or to exceed the consumer needs. Each characteristic should respond at least to one consumer requirement.

For the analyzed product, the consumer demands were classified in table 1 , and the technical characteristics found by specialists after analyzing these requirements are presented in table 2 . The arrow indicates a change of the requirement.

Table 2: Technical characteristics

\begin{tabular}{cc}
\hline Characteristics & Evolution \\
\hline Upper materials & - \\
Lining materials & - \\
Color & - \\
Air permeability & $\uparrow$ \\
Water permeability & $\uparrow$ \\
Upper elasticity & $\uparrow$ \\
Sole materials (density) & - \\
Sole hardness & $\downarrow$ \\
Lock system & - \\
\hline
\end{tabular}

\section{Establish the Product Concept}

The purpose of this phase is to compare each requirement with every characteristic in order to identify a connection and to determine the intensity (strong, medium, weak, null) for each interaction. This stage can become very complicated because each consumer demand can influence several characteristics; the higher the number of requirements, the harder it will be to build the matrix for this phase. To make it easy, symbols or color codes can be used, as follows:

Code 9; Purple - strong connection;

Code 3; Green - medium connection;

Code 1; Yellow - weak connection;

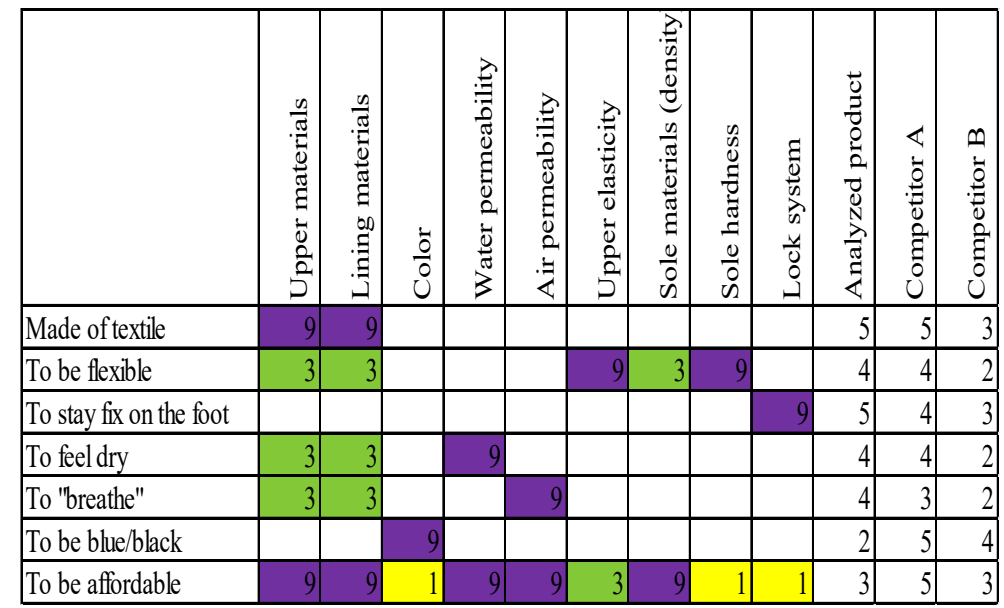

Figure 1. Connections between consumer needs and technical characteristics 
A white box represents the absence of any connection.

Using symbols or color codes the Quality House becomes more friendly and easy to be understood by consumers who lack experience/ knowledge about technical terms in footwear. After filling in the matrix, it must be verified to see if there are blank rows or columns; in this case there is no link between consumers' requirements and technical characteristics.

For example if the customer wants to feel his feet dry (not to sweat), this means, in technical characteristics, a strong connection (9) with permeability and a weak connection (3) with the raw materials for linings and the upper, thereby the sole hardness has no influence on consumer's initial demand.

The "roof" of the Quality House is represented by establishing interaction between technical design characteristics. The "roof" will have the shape of a triangle table placed above the technical features. The code color used is:

Code +9; Purple - strong positive connection;

Code +3 ; Green - positive connection;

Code -3; Blue - negative connection;

Code-9; Grey-strong negative connection;

The QFD team should use the same code color in each step. This diagram helps the QFD team to identify the characteristics which are in conflict because compromises will have to be made. If these compromises are not resolved in the design stage, it is possible to make some changes later which means higher costs and customer demands will not be satisfied completely resulting an improperly quality product.

Making decisions regarding this compromise is a difficult process that involves many departments in the company, and ultimately leads to a short period of obtaining the product.

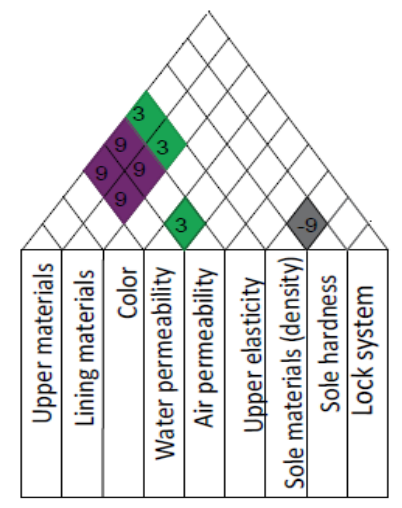

Figure 2. Connections between technical design characteristics

\section{Preliminary Design of Product}

Preliminary design of product consists in comparing, by consumer and the QFD team, three products: the analyzed product, Competitor A, Competitor B (similar products of competitors) and evaluation of requests and technical features. This stage includes two phases: the first one is competitiveness evaluation from the point of view of the consumer and the second one refers to the technical competitiveness evaluation.

1. Evaluation from the point of view of the consumer

For each requirement the consumer indicates a number on a scale from 1 to 5 regarding competitiveness of the product under review compared to the products of Competitor $A$ and Competitor B (one means weak and five strongest). The consumer also makes a hierarchy of these three products.

This method of evaluation shows whether the client claim is fulfilled, on one hand, and highlights the areas of the company that need to be changed in order to improve the design process, on the other hand.

Based on this analysis, strengths and weaknesses can be identified; the weaknesses can be improved by redesigning. 


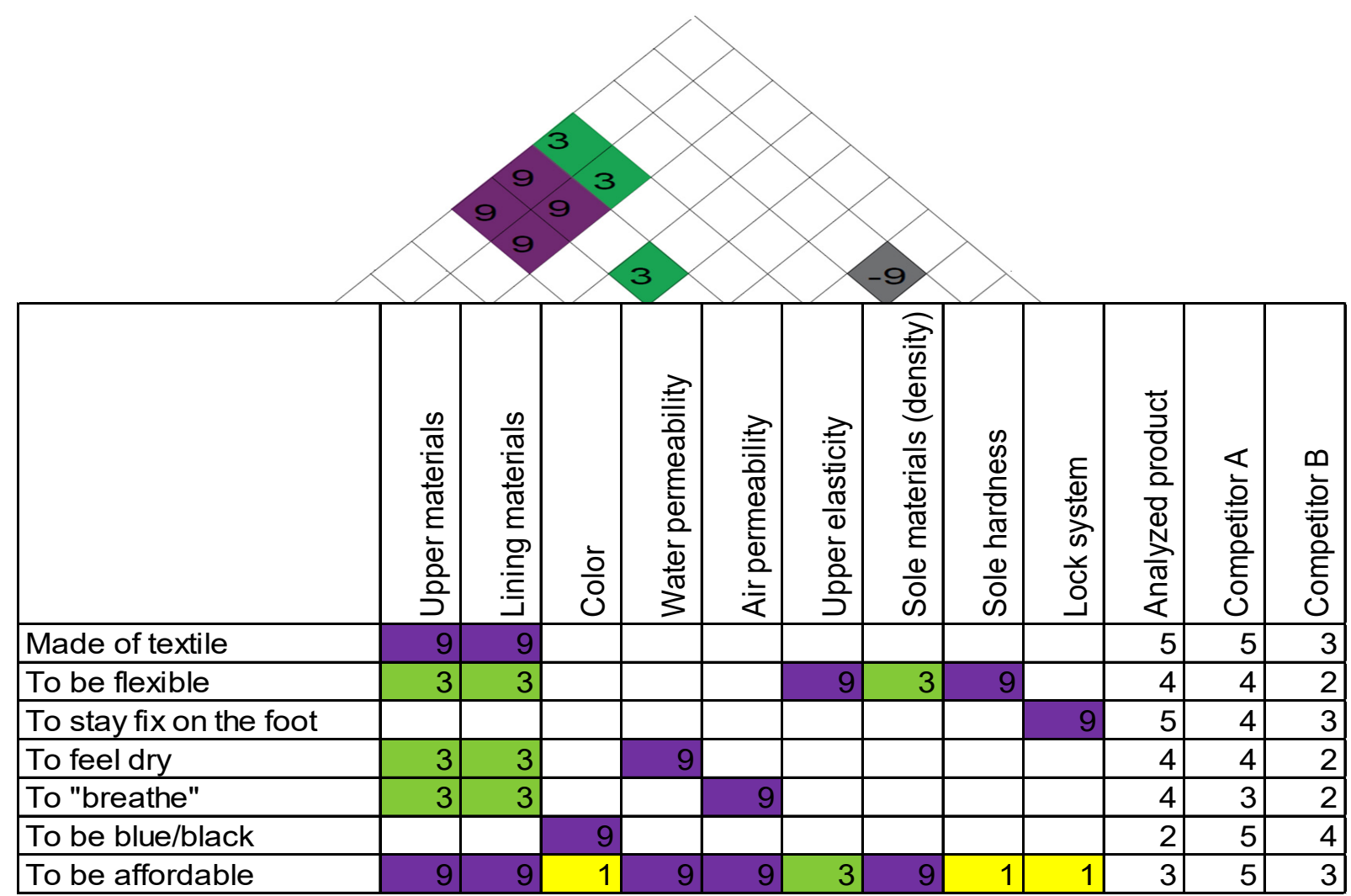

Figure 3. Requirements Matrix - technical characteristics with evaluation of the competitiveness of the products

The house "foundation" includes the size and the measure unit of each characteristic making a technical assessment of the product analyzed towards the two competitors.

2. Technical competitive evaluation

This technical analysis is very useful to identify some issues that have been neglected by QFD team in the design process. If there is a strong connection between a technical descriptor and a consumer requirement, then the competitiveness evaluation from the point of view of the consumer should be compared with the technical competitiveness evaluation.

If the technical evaluation shows that the analyzed product is superior than competitors' products, then the evaluation from the point of view of the consumer should indicate a better grade. If there are some differences in consumer perception it means that there are design errors that need to be corrected or eliminated.

\section{Final Constructive Design of the Product}

The consumer should establish the importance of each request, that is why the quality house will grow with new columns which contain, among relative importance, four elements: target value, scale-up factor, sales point and absolute weight.

Relative importance is calculated by the QFD team for each technical descriptor.

To determine the relative importance, a survey and a scale from 1 to 10 are used, where 10 represents maximum importance and 1 minimum importance.

The QFD team must be very careful to quantify these values because the client's actions may not accurately reflect the perceived importance. For example a consumer can be influenced by the shoe brand instead of the footwear features. 


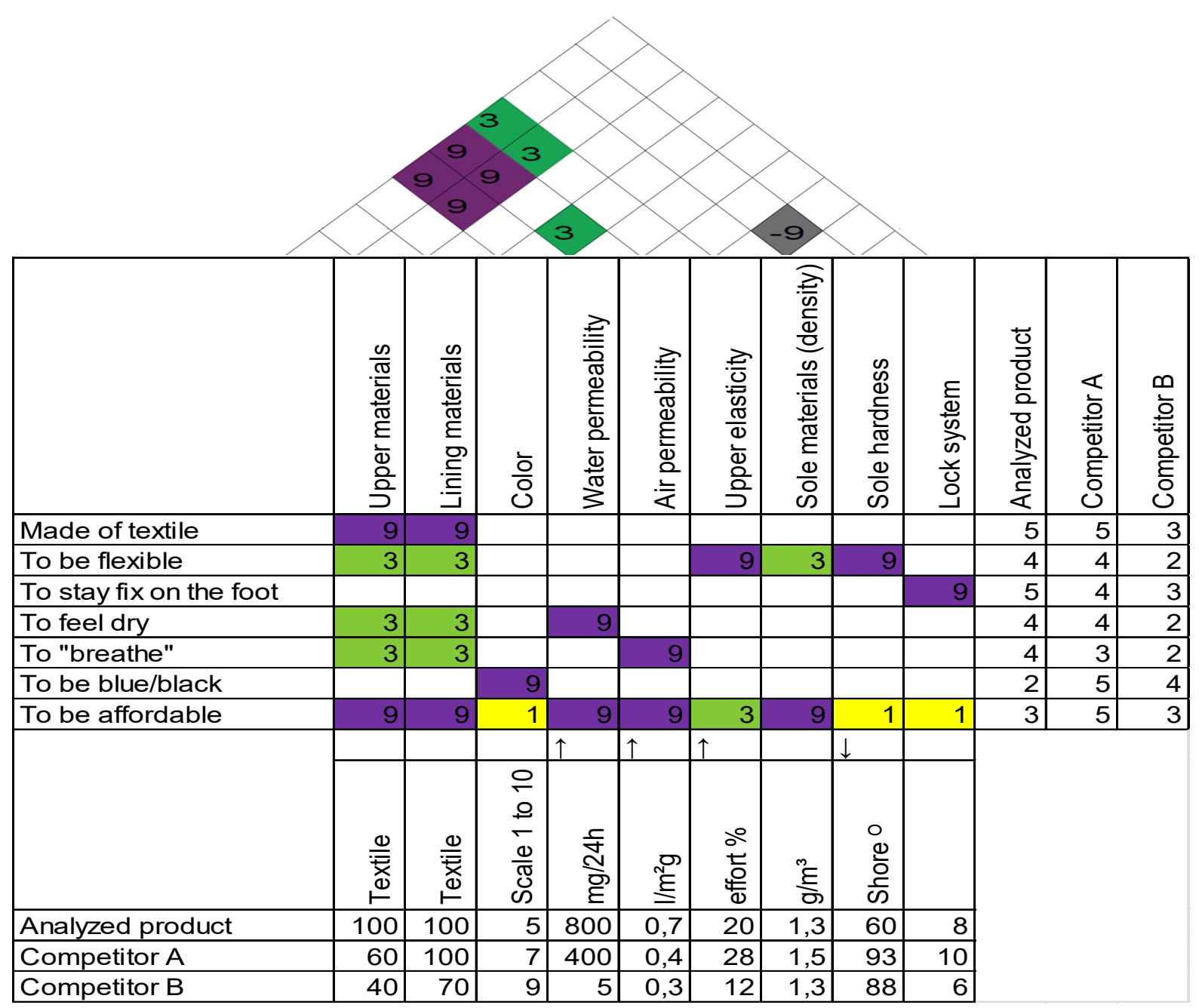

Figure 4. Requirements Matrix - technical characteristics with evaluation of the competitiveness of the products 


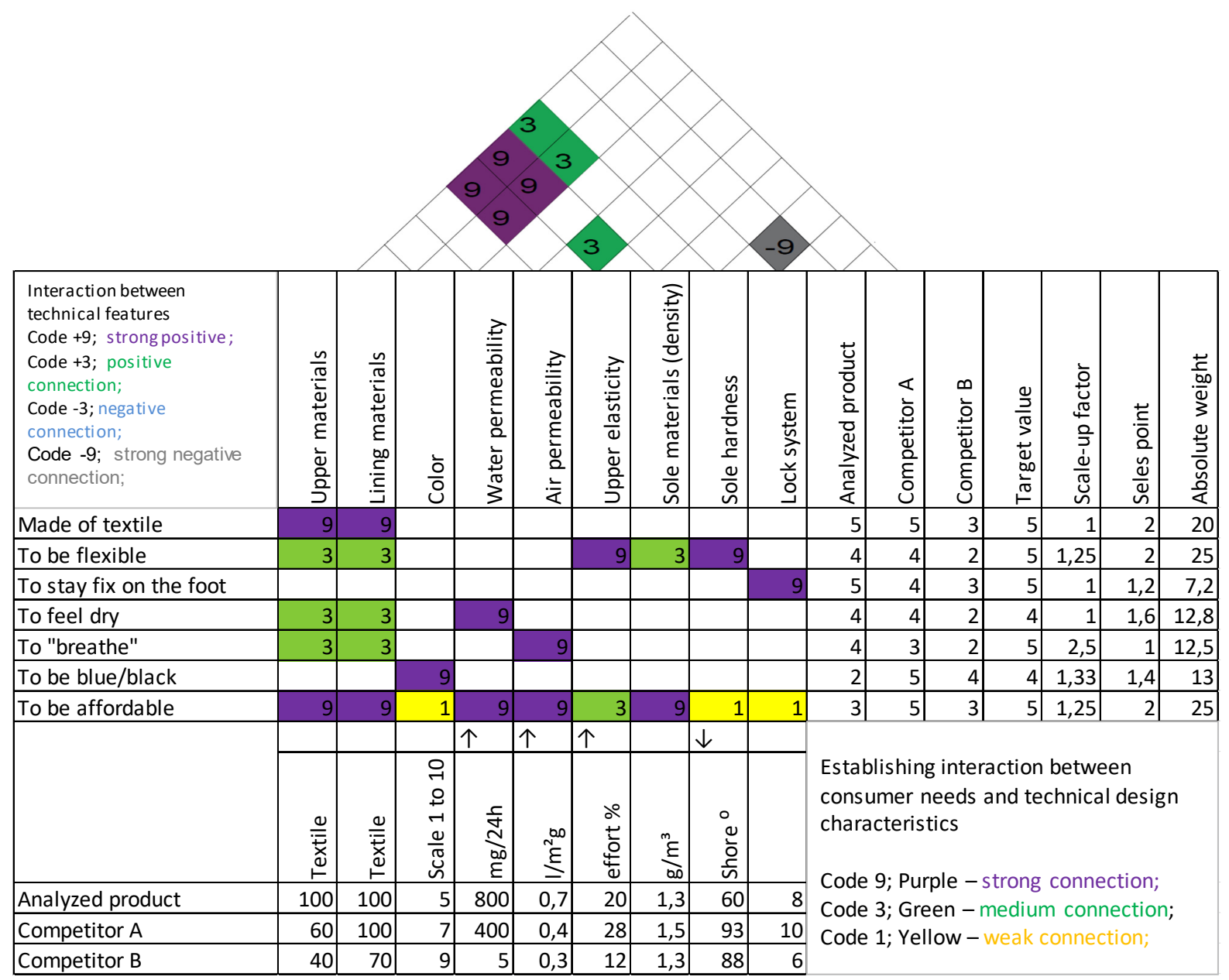

Figure 5. Requirements Matrix - the importance of the requirements 


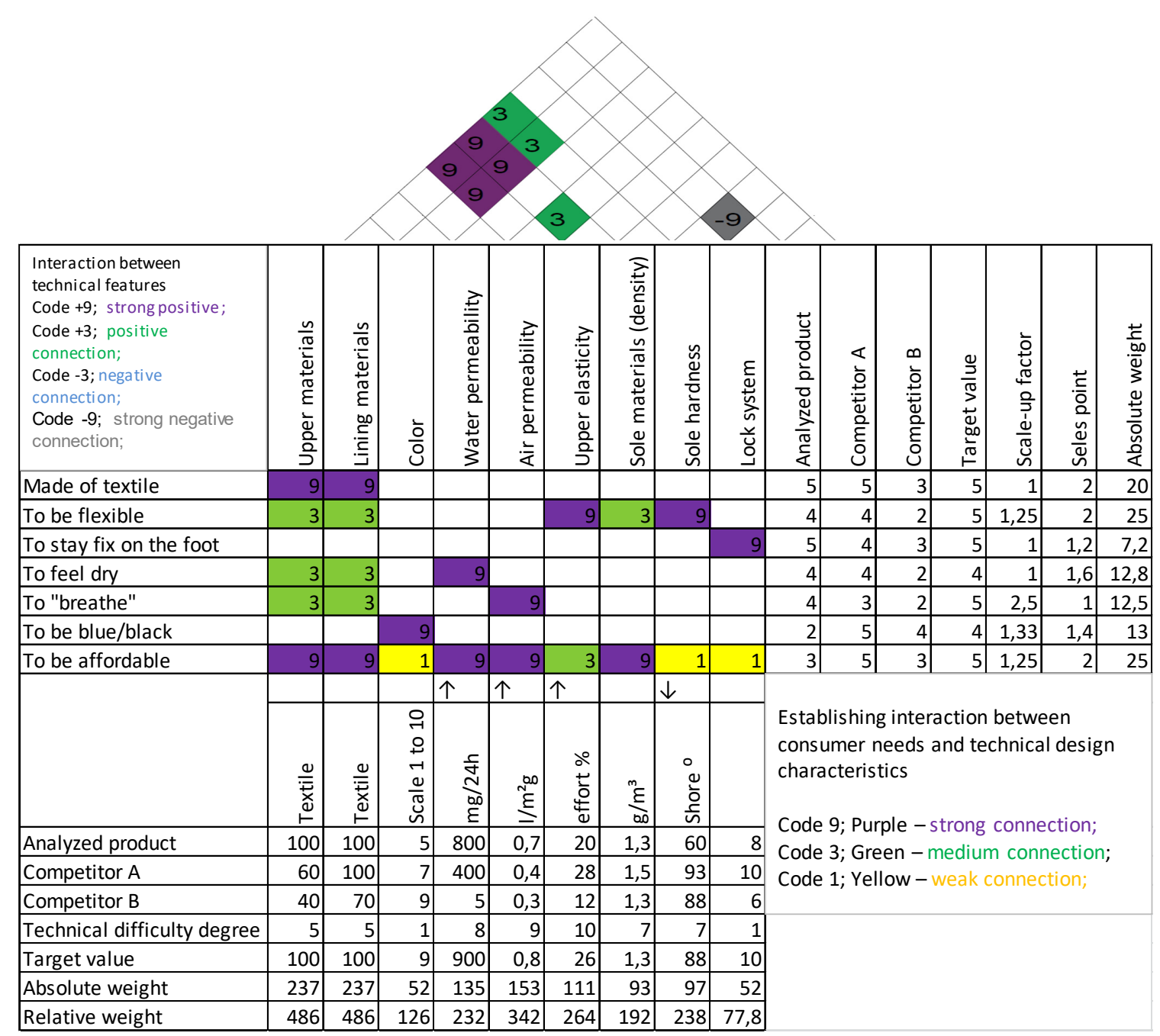

Figure 6. Requirements Matrix - technical design characteristics 


\section{Target value}

The column for target value is using the same scale used for competitive evaluation for the analyzed product ( 5 the most competitive, 1 the lowest level of competitiveness). In this column the QFD team is developing its strategy.

\section{Scale-up factor}

Scale-up factor is the ratio between the target value and competitive evaluation of the analyzed product by each demand of consumer. Usually, the value of scale-up factor is higher than 1 , because the product will be accepted by the QFD team only if the consumer's request is satisfied. If the target value and competitive evaluation of the analyzed product are equal, then the scale-up factor is 1 , which means that the clients are pleased with the shoes. When the scale-up factor is higher than 1 , then the product needs to be improved which means extra efforts for the company.

\section{Sales point}

Sales points are represented by those features of analyzed product, which are very appreciated by consumers, and are better than

competitors'.

The QFD team collaborate with marketing department will assign values from 1 to 2 for each consumer requirement, depending on importance of demand which, in the end, will result in increased sales for the analyzed product.

\section{Absolute weight}

The formula for calculating the absolute weight is:

The values can be used in the planning process for developing the product. Sometimes the values can be rounded in order to have an easy representation.

5. Prioritizing Requirements - technical design characteristics

It is important to establish the order of priorities about technical design features because it is very useful to understand and decide which one will be developed in the next stages of QFD.

To finish the quality house we have to create four columns for the following elements: technical difficulty degree, target value, absolute weight and relative weight.

Absolute weight $=($ Relative importance $) *($ Scale-up Factor $) *($ Sale point $)$

6. Technical difficulty degree

Technical difficulty degree assumes setting a level of difficulty for each technical design feature, using a scale from 1 to 10, where 1 represents the minimal difficulty and 10 maximum difficulties. The product improvements costs will be determined based on this evaluation.

\section{Target value}

Each technical descriptor will receive a target value; this is an objective action which defines the values to be obtained to improve the targeted descriptor. The QFD team establishes the target value so as to reach or exceed consumer value.
To stay on the market the analyzed product should have better features than competitors' product.

\section{Absolute weight}

For calculation of the absolute weight, the team transforms in numbers the color codes used to indicate the connection between consumer requirements and technical design characteristics. To calculate the absolute weight must sum the products obtained from multiplication of relative importance with the code for each requirement. The formula used is:

Absolute weight $=$ Sum (Value of each connection between consumer requirements and technical design characteristics * Relative Importance)

\section{Relative weight}

Relative weight is calculated similarly to absolute weight, but indicates bigger values and shows the design area which should be improved.
Relative weight takes into consideration information regarding scale-up factor and sale point. Because of this, relative weight shows the impact of technical features on consumer requirements. 


\section{CONCLUSIONS}

QFD helps companies:

- To highlight consumer needs;

- To identify/find the most significant features of the product and to remove some aspects without affecting sells;

- To design a new product or to redesign an existing one;

- To observe where the company is situated on the market and to compare it with competitors;

- To establish objectives for the technical characteristics that should be in the future.

\section{REFERENCES}

1. Akao, Y., Quality Function Deployment: Integrating Customer Requirements into Product Design, Taylor \& Francis, UK, 2004.

2. Bruce, H.S. et al., A conceptual QFD planning model, Int J Qual Reliab Manag, 18, 8, 2001, 796-812, https://doi. org/10.1108/02656710110401187.
3. Herzwurm, G., The leading edge in QFD for software and electronic business, Int J Qual Reliab Manag, 20, 1, 2003, 36-55, https://doi. org/10.1108/02656710310453809.

4. Lockamy, A., Khurana, A., Quality function deployment: total quality management for new product design, Int J Qual Reliab Manag, 12, 6, 1995, 73-84, https://doi. org/10.1108/02656719510089939.

5. Parkin, N. et al., The introduction of QFD in a UK original equipment Manufacturer, Managerial Auditing Journal, 2002, 43-54, https://doi. org/10.1108/02686900210412234.

6. Rusu, B., Strategic development of consumeroriented footwear products (in Romanian), Stage I, INFOSOC - CEEX Program 106/2006.

7. Scheurell, D.M., Beyond the QFD House of Quality: Using the Downstream Matrices, World Class Design to Manufacture, 1, 2, 1994, https://doi. org/10.1108/09642369210054216.

(C) 2018 by the author(s). Published by INCDTPICPI, Bucharest, RO. This is an open access article distributed under the terms and conditions of the Creative Commons Attribution license (http:// creativecommons.org/licenses/by/4.0/). 